\title{
津波避難困難時間の算定を目的とした 強震動の評価一山形県酒田市飛島を例として一
}

\author{
山内 政輝 1 - 秦 吉弥 2 - 鍬田 泰子 3 - 小山 真紀 4 - 中嶋 唯貴 5 \\ 1 学生会員 大阪大学 大学院工学研究科（干565-0871 大阪府吹田市山田丘2-1） \\ E-mail: myamauchi@civil.eng.osaka-u.ac.jp \\ 2 正会員 大阪大学 大学院工学研究科（广565-0871 大阪府吹田市山田丘2-1) \\ E-mail: hata@civil.eng.osaka-u.ac.jp \\ 3 正会員 神戸大学 大学院工学研究科（干657-8501 兵庫県神戸市灘区六甲台町1） \\ E-mail: kuwata@kobe-u.ac.jp \\ 4 正会員 岐阜大学 流域圈科学研究センター（†501-1193 岐阜県岐阜市柳戸1-1） \\ E-mail: maki_k@gifu-u.ac.jp \\ 5 正会員 北海道大学 大学院工学研究院 ( $\bar{T} 060-8628$ 北海道札幌市北区北13条西8丁目) \\ E-mail: nakashima@eng.hokudai.ac.jp
}

\begin{abstract}
山形県酒田市から北西に約40kmの日本海に浮かぶ飛島は，想定地震が発生した際，約五分で巨大津波 の来襲が予想されている。そこで本稿では，まず，島内の津波来襲予想地域において常時微動計測を高密 度に実施し, 得られた記録に基づき地盤震動特性を評価した。次に, 評価した地盤震動特性とアスペリテ イモデルを組合せた強震波形計算を実施し, 強震動作用中の避難困難時間を算定した. 最後に, 津波来襲 時間と避難困難時間の関係性を踏まえて, 強震動の作用が津波避難に及ぼす影響について言及した。
\end{abstract}

Key Words : strong motion, tsunami evacuation, time management, Sea of Japan, Tobishima

\section{1. はじめに}

南海トラフ巨大地震の震源域では, 震度6強〜震度7の 非常に大きな強震動の作用が予想1)されている。一方で, 震源域近くの沿岸部では，南海トラフ巨大地震の発生後 数分で巨大津波の来襲も予想1されており，上述した強 震動の作用が住民等の津波避難に影響を及ぼすことが予 想される．この点に関して著者ほが2゙，2011年東北地 方太平洋沖地震による津波来襲地域での観測地震動の作 用が津波避難に及ぼした影響について検討を行うために, 強震動作用中の避難困難時間の算定を試みている。また， 著者ほか ${ }^{338)}$ は, 南海トラフ巨大地震の発生によって津 波の早期来襲が予想されている静岡県334. 和歌山県 ${ }^{5,0}$ ・ 高知県 ${ }^{7}$. 宮崎県 ${ }^{8}$ の沿岸域を対象として, 津波来襲予想 地域において強震動を高密度に予測し, 強震動の作用が 津波避難に及ぼす影響について検討を行っている.さら に，著者ほか ${ }^{9} は ， 1993$ 年北海道南西沖地震の巨大津波 の早期来襲により甚大な被害が発生した北海道奥尻島青 苗地区を対象に本震時に作用した強震動を推定し，推定 地震動に基づいた避難困難時間を算定している.

上述した一連の先行研究2)-9)では, 我が国の太平洋沿 岸における津波来襲地域・来襲予想地域を主に対象フィ
ールドとしていること, 強震動を対象とした断層モデル 1)が既に提案・評価されていることから対象フィールド での強震動の推定・予測が比較的容易であること，など が大きな特徵として挙げられる。これを言い換えれば, 日本海沿岸における津波来襲予想地域を対象とした検討 は，これまで十分に行われているとは言い難い.

日本海に浮かぶ有人離島である山形県酒田市飛島 (図1参照) は, その直下に震源域を有する想定地震 (以後, 飛島直下地震と呼ぶ)が発生した場合, 約五分で巨大津 波の来襲が予想10)されている，そこで本稿では，国土交 通省 ${ }^{10)}$ が津波伝播や遡上の計算において採用した特性化 震源モデルを強震動予測に援用することで，強震動継続 時間を踏まえた避難困難時間に関する定量的な評価を実 施し, 強震動の作用が津波避難に及ぼ寸影響について詳 細な検討を行った結果を報告する。

\section{2. 断層モデルの構築}

図-1に構築した飛島直下地震の断層モデルと飛島の位 置関係，および表-1にモデルパラメータの一覧をそれぞ れ示寸. 以下, 表-1の上から記載順に, パラメータの設 
定根拠について述べる.

まず，巨視的パラメータである断層の走向および傾斜 については，日本海における大規模地震に関する調査検 討会 ${ }^{10}$ による津波を対象とした断層モデルの形状に関す る特性值をそれぞれ採用した，次に，微視的パラメータ であるアスペリティ関する諸量(地震モーメント，長さ， 幅，ライズタイム)については，飛島に近い日本海域を 震源とする歴史地震である1983年日本海中部地震の特性

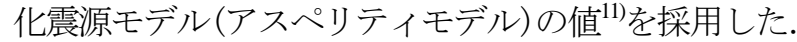
アスペリティと破壊開始点の配置(図-1参照)については, 現行の港湾基準 ${ }^{12)}$ を参考にアスペリティの破壊が飛島に 向かって進展するような (具体的には, 試行錯誤により 後述する予測地震動に基づく瞬間計測震度の継続時間が 比較的長くなるような)配置を採用し，アスペリティの 中心深さは $10 \mathrm{~km}$ とした．最後に，その他のパラメータ $(Q$ 值 (地震基盤上での地震動の減衰を表寸值), 密度, せん断波速度，破壊伝播速度)についても，1983年日本

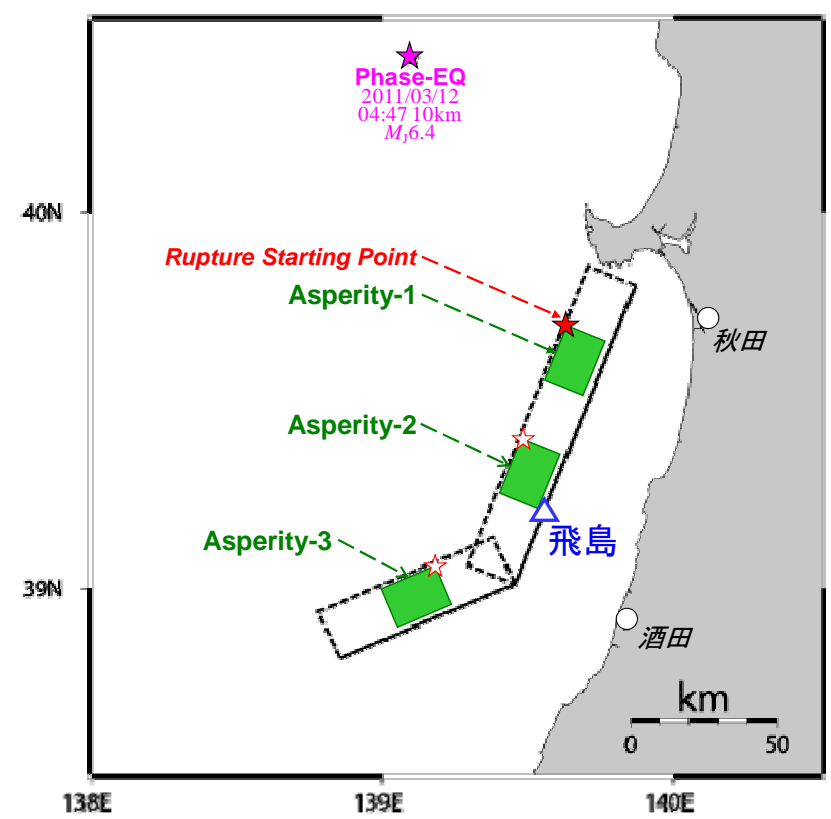

図-1 日本海離島の飛島とその直下地震の断層モデル

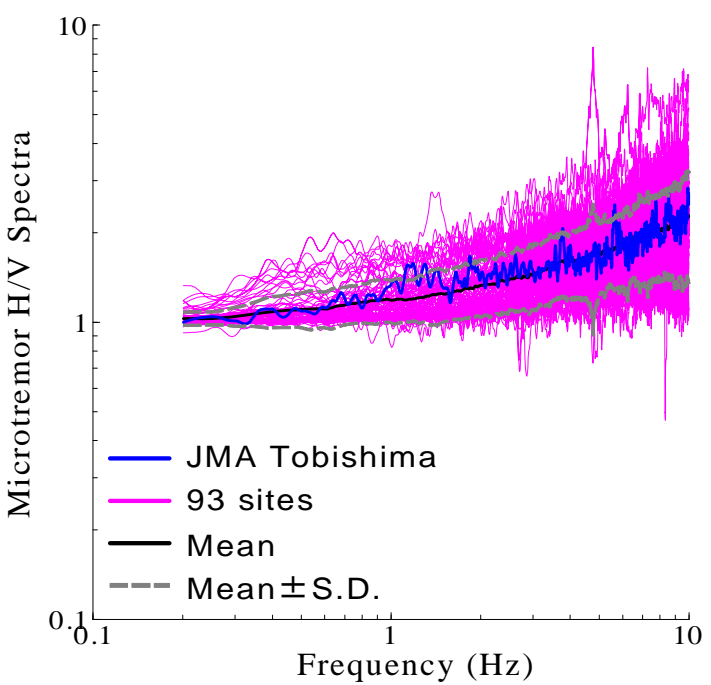

図-2 飛島内における常時微動 $\mathrm{H} / \mathrm{V}$ スペクトルの比較
海中部地震の特性化震源モデル(アスペリティモデル)の 值 ${ }^{11)}$ を採用した。

\section{3. 高密度常時微動計測の実施}

飛島の津波来襲予想地域内において避難困難区域を具 体的に抽出するためには，避難困難時間と避難所要時間 の評価に関する基点は共通とすべきである．地盤震動特 性を考慮して避難困難時間を評価するためには，常時微 動計測の実施が必要不可久であることから，微動計測点 を共通の基点として採用する.

常時微動計測は，飛島で予想される津波来襲地域(計 93地点 $)^{10}$ および島内唯一の既存強震観測点であるJMA 飛島(図-3参照) ${ }^{13)}$ においてそれぞれ実施した．写真-1に 常時微動計測状況の一例を示寸．計測期間は，2016年9 月5６日の二日間である．計測は主に昼間に実施し，同 型の七台の微動計 (ともに白山工業(株)製の一体型微動 探査兼地震計機器 $\left.{ }^{14}\right)$ を採用した。 計測機器の諸元につ いては，文献14)を参照されたい，計測方向は水平二成 分と鉛直成分の計三成分であり，後述する常時微動 $\mathrm{H} / \mathrm{V}$ スペクトルの計算では，水平二成分の平均をとった．計 測時間は，一計測点あたり約30分間の単点計測とした.

常時微動H/Vスペクトルの計算処理方法 ${ }^{15)}$ としては, まず，微動の加速度時刻歴に対して0.1Hzのハイ・パス

表-1＼cjkstart設定した断層モデルパラメータの一覧

\begin{tabular}{cccc}
\hline & Asperity-1 & Asperity-2 & Asperity-3 \\
\hline Strike (deg.) & 200 & 185 & 202 \\
Dip (deg.) & 45 & 45 & 45 \\
\hline Seismic moment (Nm) & $1.32 \times 10^{20}$ & $1.32 \times 10^{20}$ & $0.88 \times 10^{20}$ \\
Length (km) & 17.5 & 17.5 & 17.5 \\
Width (km) & 17.5 & 17.5 & 17.5 \\
Rise time (s) & 1.40 & 1.40 & 1.40 \\
Partition number & $3 \times 3 \times 3$ & $3 \times 3 \times 3$ & $3 \times 3 \times 3$ \\
\hline$Q$ value & & $114 \times f^{0.92}$ \\
Density (kg/m $\left.{ }^{3}\right)$ & & $3.1 \times 10^{3}$ \\
Shear wave velocity $(\mathrm{km} / \mathrm{s})$ & & 3.9 \\
Rupture velocity $(\mathrm{km} / \mathrm{s})$ & \multicolumn{3}{|c}{3.12} \\
\hline
\end{tabular}

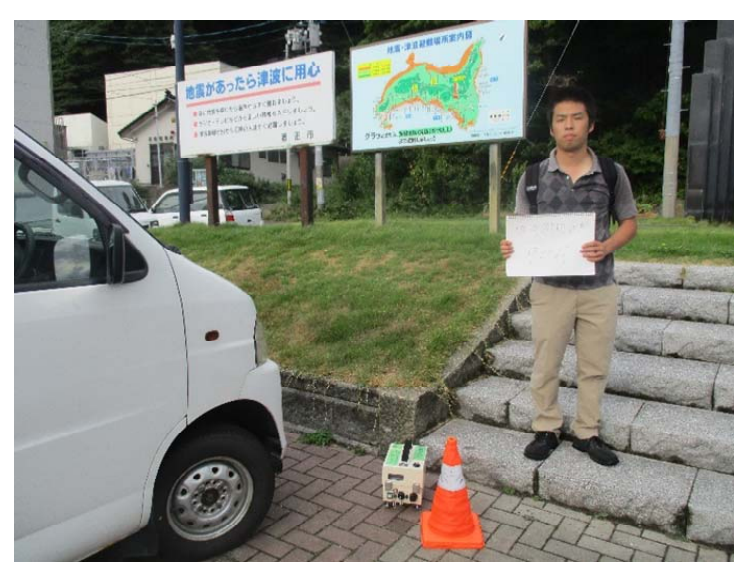

写真-1 飛島での常時微動計測状況の一例 
フィルターを施し，雑振動が比較的小さい163.84秒の区 間を七区間抽出し，フーリエスペクトルの計算を行い， バンド幅0.05HzのParzen Windowで平滑化した後に，H/V スペクトルを算出し，七区間の平均をとった。評価振動

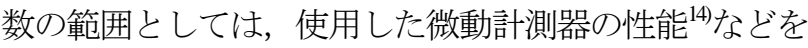
考慮して0.2〜10Hzとした.

図-2 は，JMA 飛島(図-1 参照)における常時微動 H/V スペクトルと，飛島の津波来襲予想地域内 (93 地点)の 常時微動 H/V スペクトルを重ね合せたものである．図-2 に示すとおり，津波来襲予想地域の $\mathrm{H} / \mathrm{V}$ スペクトル(周 波数ごとの平均值およびその標準偏差の分布) と JMA 飛 島における $\mathrm{H} / \mathrm{V}$ スペクトルの比較において，両者の特 徴(ピーク周波数やスペクトル形状など)が良い一致を示 している．すなわちこれは，JMA 飛島における地盤震 動特性が津波来襲予想地域のほぼ全域の地盤震動特性と して代表できる可能性が高いことを示唆するものである

図-3は，常時微動H/Vスペクトル(図-2参照)のピーク 周波数を地形図上にプロットしたものである. 図-3に示 すとおり, 常時微動H/Vスペクトルの差異 (図-2参照)に 起因して，ピーク周波数の分布においても一定のバラッ キが確認できる．図-4，図-5，図-6は，飛島を対象とし た産総研地質図 ${ }^{16)}$ ，山形表層地質図 ${ }^{17)}$ ，地形区分図 ${ }^{177}$ で

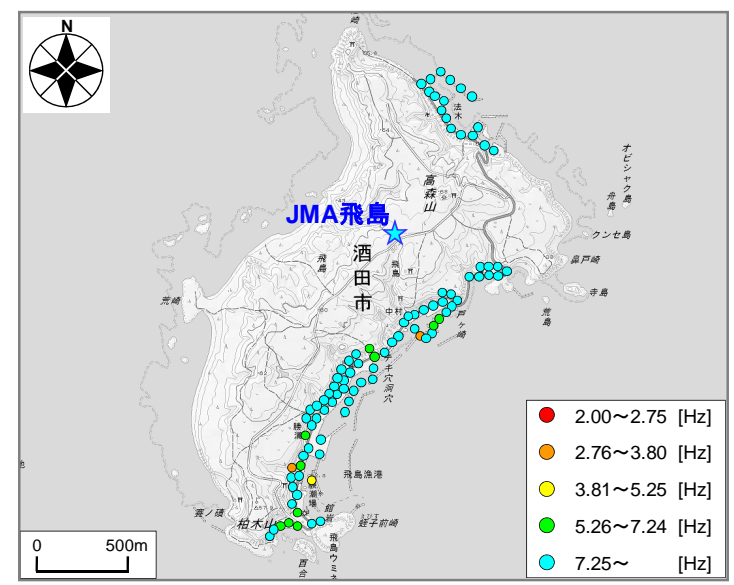

図-3 常時微動 $\mathrm{H} / \mathrm{V}$ スペクトルのピーク周波数の分布

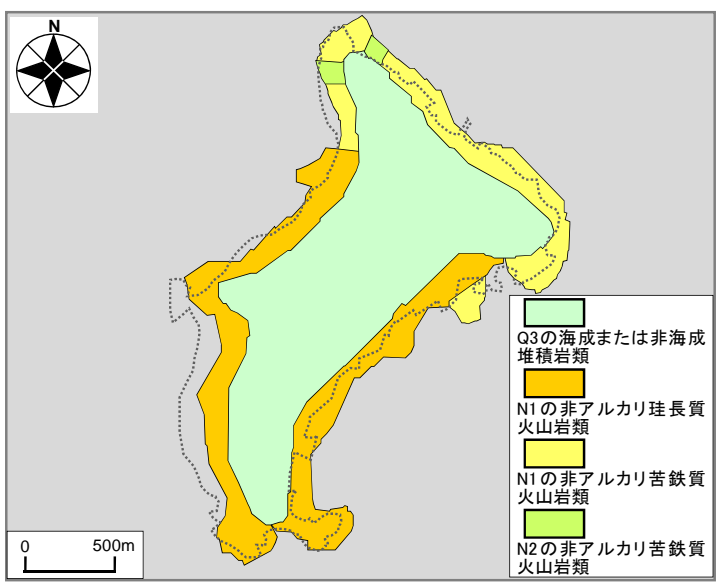

図-4 産業技術総合研究所 ${ }^{16}$ による飛島の地質分布
ある．図-3に対して図-4・図-5・図-6を比較すると，評

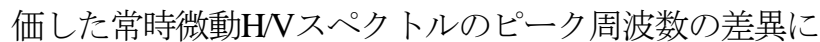
対する地形や地質の違いについて明らかな関係性を読み 取ることはできない.

よって本稿では，JMA飛島におけるサイト増幅特性 (地震基盤〜地表 : 図-7参照 ${ }^{18}$ ) とサイト位相特性に基づ いて飛島での強震動予測を実施することとした。ここに, サイト位相特性については，JMA飛島での観測記録の中 で，飛島直下地震の震源域 ${ }^{10}$ の比較的近くで2011年3月 12 日4時47分に発生した秋田県沖を震源とする気象庁マグ ニチュード6.4の地震 (Phase-EQ : 図-1参照)によって JMA飛島で得られた観測地震動(図-8参照)を採用した。

\section{4. 強震動予測の手法}

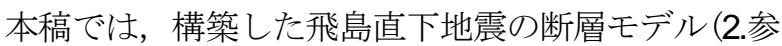
照) と経験的サイト増幅・位相特性を考慮した強震波形 計算手法 ${ }^{199}$ の組合せに基づき強震動を推定した。当該計 算手法 ${ }^{18)}$ では式(1)により統計的グリーン関数を生成する。

$$
A(f)=S(f) \cdot P(f) \cdot G(f) \cdot \frac{O(f)}{|O(f)|_{p}}
$$

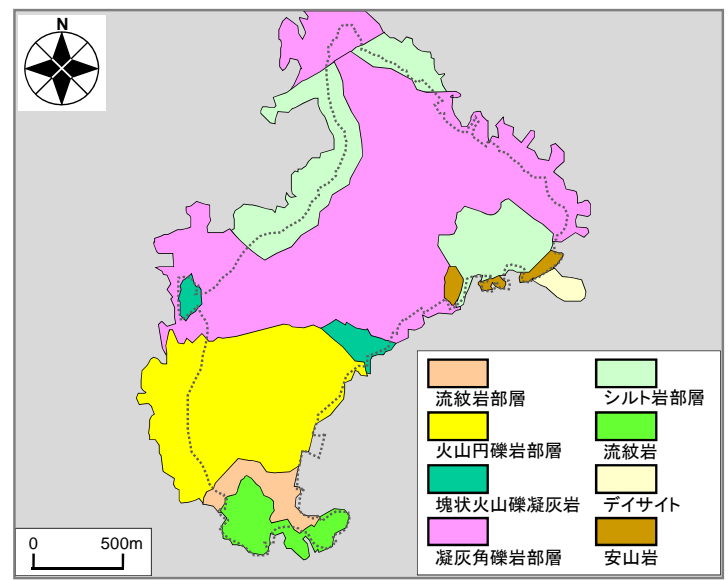

図-5 山形応用地質研究会 ${ }^{17}$ による飛島の地質区分

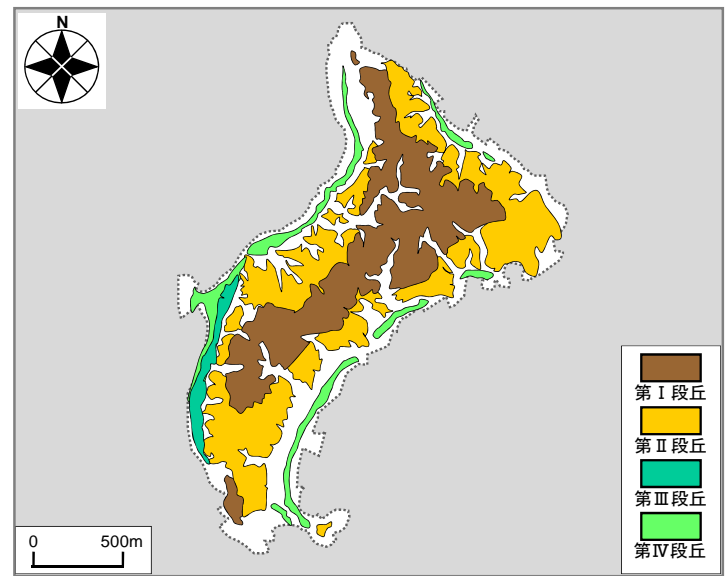

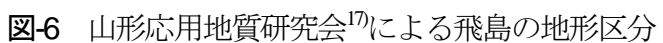


ここに，A(f)は地表における統計的グリーン関数のフー リ工変換で複素数, $S(f)$ は中小地震の震源特性 ${ }^{20)}$ で実数, $P(f)$ は伝播経路特性 ${ }^{20)}$ で実数, $G(f)$ はサイト増幅特性(図-7 参照) で実数, $O(f)$ は中小地震観測記録(図-8参照)のフー リエ変換で複素数, $|O(f)| p$ はその絶対值に対してバンド 幅0.05HzのParzen Windowを適用したものである.

式(1)からわかるように，本手法では，統計的グリー ン関数のフーリ工振幅は震源特性・伝播経路特性・サイ 卜特性の積として求め, 統計的グリーン関数のフーリエ 位相としては現地で得られた中小地震記録のフーリエ位 相を用いる. 式(1)をフーリエ逆変換し，経験的グリー ン関数法と同様の重叔合わせを行うことで，大地震によ る波形が求まる．なお，Parzen Window(添字p) は因果性 を満足する地震波を生成する目的で用いられている ${ }^{199}$.

なお，図-1に示寸ように，飛島は，想定震源域の極近 傍(直上)に位置していることから，想定地震時に地盤が 非線形挙動を示寸可能性が高いと考えられる. そこで本 稿では，表層地盤の非線形挙動の効果を考慮してグリー ン関数を補正する方法 ${ }^{21)}$ を採用し，S波速度の低下率を 表すパラメータ $v_{1}$ (非線形性の影響が大きいほど低下) と 堆積層における平均的な減衰定数の増分を表すパラメー

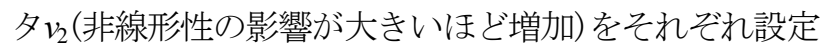
した。 具体的には，JMA飛島とK-NETいわきのサイト増 幅特性 ${ }^{18,22}$ )が比較的類似していることから (図-7参照), 2011年東北地方太平洋沖地震によるK-NETいわきでの実 績值 $\left(v_{1}=0.90, v_{2}=0.01\right)^{21)}$ を採用した.

\section{5. 予測結果とその応用}

図-9(a),(b) に飛島直下地震時の飛島 (JMA飛島) におけ る推定地震動 (水平動) の加速度時刻歴を示寸. 一方で, 図-9(c) は, 飛島 (JMA飛島) における強震動作用中の避 難困難時間である．避難困難時間は，予測地震動の加速 度波形 (図-9(a), (b) 参照) において瞬間計測震度 (水平二 成分合成 ${ }^{23}$ の時刻歴を計算し(図-9(c)参照), 先行研究 ${ }^{24}$ による知見を参考に，瞬間計測震度が4.0を下回るまで の連続時間とした. 図-9(c)に示寸ように, 想定地震時
における飛島 (JMA飛島) での避難困難時間は，136s と算 定され，飛島では強震動の作用によりおおよそ二分強に わたって住民等が避難行動に移ることができない可能性 が高いことが読み取れる. すなわちこれは，上述したと おり想定地震による飛島への津波来襲時間は約五分と予 想苗されていることから，そのうち約半分は津波避難困 難時間によって占められる，言い換えれば，住民等が避 難のために本来持ち合わせている時間の約半分が強震動 の作用によって失われることを示唆するものである.

図-10 は，常時微動計測地点 (図-3 参照)から計測地点 最近に位置する避難地点(高台等の既存施設)までの避難 所要時間の分布である. 避難所要時間は, ウォーキング 実験(図-10 枠内写真参照) 25 )実施し, 得られた結果に 基づいて評価した。ここに，避難困難時間の経過後すぐ に避難を開始する確率は低いものの，その確率の推定は 現状困難であるため, 本稿では先行研究の知見 ${ }^{26}$ に基づ き避難所要時間に避難開始時間を含めていない. ウォー キング実験の実施内容については文献 25)を参照された い. なお，今後の課題の一つとして，年齢差や障害者へ の配慮等, 避難パターンのバリエーションを追加してい く必要があると考えている. 津波来襲時間の五分と津波 避難困難時間の二分強を考慮して(津波来襲時間から避 難困難時間を差し引いて), 図-10 において避難所要時

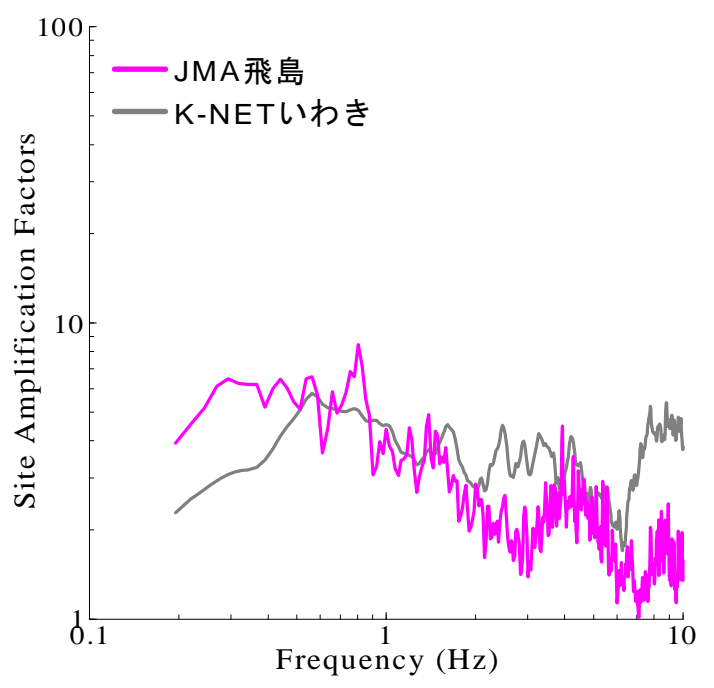

図-7 JMA飛島 ${ }^{18)}$ とK-NETいわき22)におけるサイト増幅特性

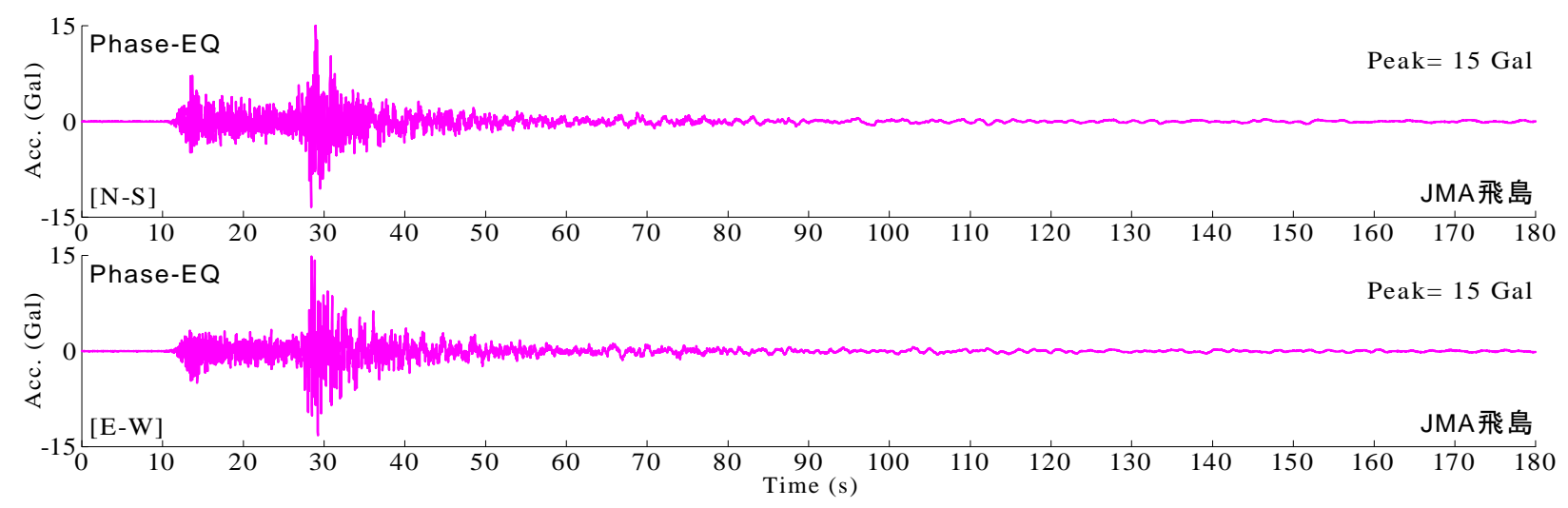

図-8サイト位相特性の評価に用いたJMA飛島での観測地震動(2011/03/12 04:47M,6.4)の加速度時刻歴 


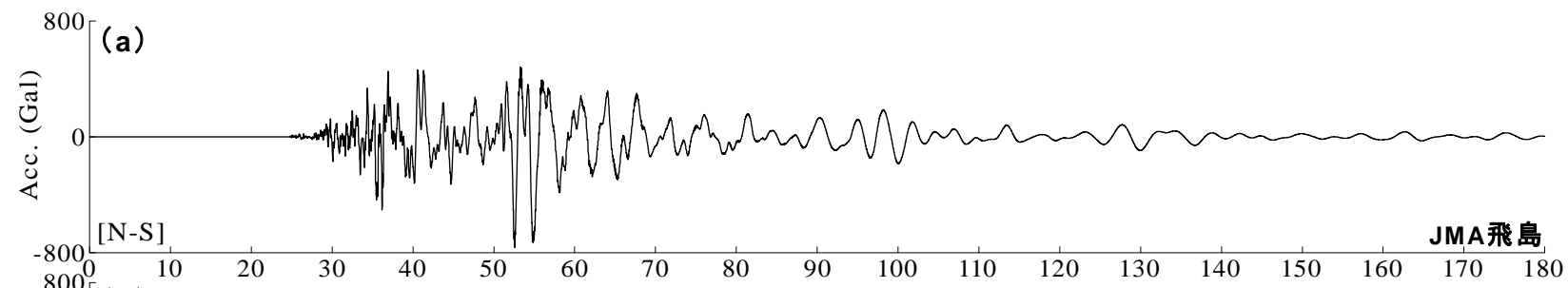

(b)
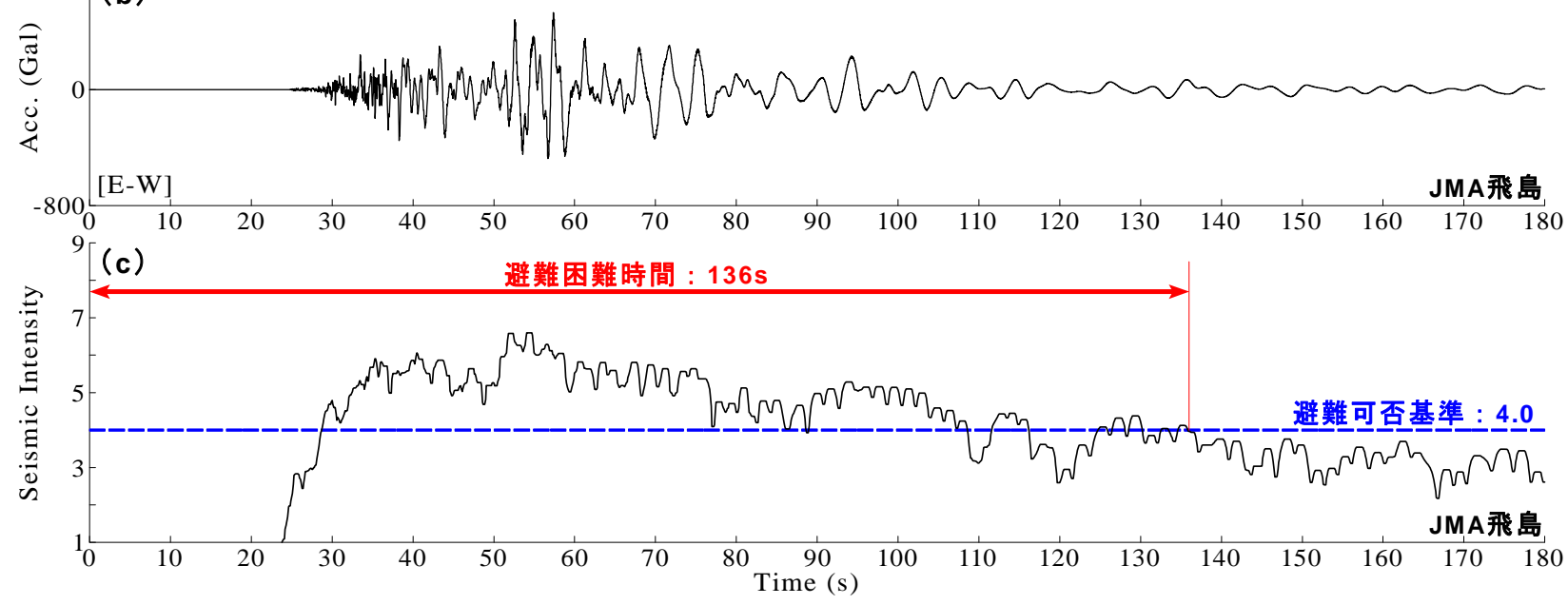

図-9 飛島直下地震による飛島での推定地震動(同図(a),(b)) と瞬間計測震度の時刻歴に基づく避難困難時間の評価(同図(c))

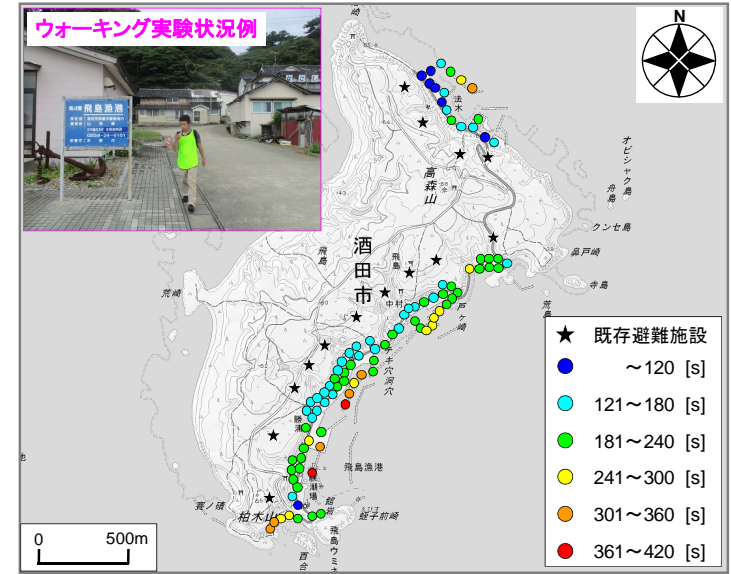

図-10 ウォーキング実験に基づく避難所要時間の分布

間が三分以上(オレンジ色・赤色)の地域は，主に海岸に 近い地域を中心に比較的広範囲に及んでいるのが確認が でき，これらの地域を中心に今後何らかの津波避難施設 (津波避難タワーなど) を新設する必要性が示唆される.

\section{6. まとめ}

本研究では，日本海に浮かぶ山形県酒田市の飛島を対 象フィールドとし，飛島直下の想定地震が発生した場合 に，強震動の作用が津波避難に及ぼす影響について常時 微動計測結果などに基づいて検討を行った。その結果, 飛島における津波来襲時間は約五分と予想されているの に対して，飛島 (JMA飛島)における強震動作用中の避難 困難時間は136s (二分強) と算定され，約半分が津波避難
困難時間によって占められる，言い換えれば，住民等が 避難のために本来持ち合わせている時間の約半分が強震 動の作用で失われる可能性が高いことが明らかとなった。 今後は，日本海に浮かぶ他の離島に対しても同様のア プローチを適用していきたいと考えている.

謝辞：常時微動計測の実施にあたつては，飛島の住民の 皆様などに大変お世話になりました。本研究の遂行にあ たり，公益財団法人鹿島学術振興財団2015・2016年度研 究助成「地域特性を考慮した津波避難困難区域の抽出〜 強震動予測と歩行実験によるハイブリッド評価〜」の一 部を使用しました。ここに記して謝意を表します。

\section{参考文献}

1) 南海トラフの巨大地震モデル検討会 : 南海トラフの 巨大地震モデル検討会 (第二次報告), 内閣府防災情 報ホームページ, 2012. (最終閲覧日：2017年 4 月 27 日)

2) 湊文博，秦吉弥，藤木昂，山田雅行，鍬田泰子，小 山真紀, 中嶋唯貴, 常田賢一：津波避難困難時間に 影響を及ぼす強震動の周波数帯域に関する基礎的検 討, 第 36 回地震工学研究発表会講演論文集, 土木学 会, Paper No.923, 2016.

3) 秦吉弥, 湊文博, 山田雅行, 鍬田泰子, 小山真紀, 中嶋唯貴, 常田賢一: 強震動作用中の津波避難困難 時間に関する評価精度とその向上策一南海トラフ巨 大地震における駿河湾沿岸域を対象として一，構造 工学論文集, 土木学会, Vol.62A, pp.259-272, 2016.

4) 秦吉弥, 湊文博, 常田賢一, 青木伸一, 鍬田泰子, 小山真紀 : 南海トラフ巨大地震における静岡県沿岸 域での推定地震動の作用が津波避難に及ぼす影響, 土木学会論文集 B3, Vol.72, No.2, pp.I_1-6, 2016.

5) 湊文博, 秦吉弥, 山田雅行, 常田賢一, 鍬田泰子, 
魚谷真基 : 高密度常時微動計測に基づく和歌山県串 本町における南海トラフ巨大地震の強震動評価と津 波避難に及ぼす影響, 土木学会論文集 A1, Vol.71, No.4, pp.I_123-135, 2015.

6) 湊文博, 秦吉弥, 常田賢一, 鍬田泰子, 小山真紀, 植田裕也：高密度常時微動計測・臨時地震観測に基 づく南海トラフ巨大地震における和歌山県広川町で の津波避難不可能時間算出のための強震動評価，土 木学会論文集 A1, Vol.72, No.4, pp.I_68-81, 2016.

7) 秦吉弥, 中嶋唯貴, 湊文博, 鍬田泰子, 小山真紀, 常田賢一：高密度臨時地震観測に基づく南海トラフ 巨大地震における高知県南国市津波来襲予想地域で の強震動の予測, 第 36 回地震工学研究発表会講演論 文集，土木学会，Paper No.920, 2016.

8) 湊文博, 秦吉弥, 村上啓介, 山田雅行, 鍬田泰子, 小山真紀, 中嶋唯貴, 常田賢一: 高密度臨時地震観 測に基づく南海トラフ巨大地震における宮崎市沿岸 部での津波避難困難時間算出のための強震動予測, 地域安全学会論文集, No.29, pp.53-62, 2016.

9) 湊文博, 秦吉弥, 山田雅行, 鍬田泰子, 小山真紀, 中嶋唯貴, 常田賢一 : 高密度常時微動計測に基づく 1993 年北海道南西沖地震における奥尻島青苗地区で の強震動之避難不可能時間の評価, 土木学会論文集 A1，Vol.72, No.4, pp.I_884-894, 2016.

10) 国土交通省：日本海における大規模地震に関する調 査検討会報告書，国土交通省ホームページ, 43p., 2014. http://www.mlit.go.jp/river/shinngikai_blog/daikibojishinc housa/（最終閲覧日：2017年 4月 27 日)

11) 野津厚 : 1983 年日本海中部地震 (M7.7) の特性化震源 モデル，(国研)海上・港湾・航空技術研究所港湾空 港技術研究所地震防災研究領域ホームページ, 2015. （最終閲覧日：2017年 4 月 27 日）

12）（公社）日本港湾協会：港湾の施設の技術上の基準 同解説 [上巻]，国土交通省港湾局，pp.336-341, 2007.

13) Nishimae, Y.: Observation of seismic intensity and strong ground motion by Japan Meteorological Agency and local governments in Japan, Jour. of Japan Association for Earthquake Engineering, Vol.4, No.3, pp.75-78, 2004.

14) 先名重樹, 安達繁樹, 安藤浩, 荒木恒彦, 飯澤清典, 藤原広行 : 微動探査観測システムの開発, 第 115 回 物理探査学会学術講演会論文集, pp.227-229, 2006.

15) 秦吉弥, 湊文博, 山田雅行, 常田賢一, 魚谷真基 : 和歌山県串本町における高密度常時微動計測，物理
探査, Vol.68, No.1, pp.83-90, 2015.

16)（国研）産業技術総合研究所：地質図表示システム（地 質図 Navi)，地質調查総合センターホームページ, 2013.（最終閲覧日：2017年 4 月 27 日）

17）長澤一雄, 大場總, 阿部龍市 : 飛島の地質と地形に ついて, 山形応用地質, Vol.27, pp.64-74, 2007.

18) 秦吉弥, 山内政輝, 鍬田泰子, 小山真紀, 中嶋唯貴, 大川雄太郎, 湊文博, 常田賢一：離島の津波来襲予 想地域を対象としたサイト増幅特性の評価に関する 試み, 日本地震工学会第 12 回年次大会梗概集, Paper No.P4-38, 2016.

19) 野津厚, 長尾毅, 山田雅行 : 経験的サイト増幅・位 相特性を考慮した強震動評価手法の改良一因果性を 満足する地震波の生成一，土木学会論文集 A, Vol.65, No.3, pp.808-813, 2009.

20) Boore, D. M.: Stochastic simulation of high-frequency ground motions based on seismological models of the radiated spectra, Bulletin of the Seismological Society of America, Vol.73, No.6A, pp.1865-1894, 1983.

21) 若井淳, 野津厚 : 2011 年東北地方太平洋沖地震の際 に見られた表層地盤の非線形挙動の概略的傾向，港 湾空港技術研究所資料, No.1272, 2013.

22) 野津厚, 長尾毅, 山田雅行：スペクトルインバージ ヨンに基づく全国の強震観測地点におけるサイト増 幅特性とこれを利用した強震動評価事例, 日本地震 工学会論文集, Vol.7, No.2, pp.215-234, 2007.

23) Kuwata, Y. and Takada, S.: Instantaneous instrumental seismic intensity and evacuation, Journal of Natural Disaster Science, Vol.24, No.1, pp.35-42, 2002.

24) 鍬田泰子, 齊藤栄 : 瞬間計測震度を用いた摇れ最中 の避難行動可能時間の定量化, 日本地震工学会論文 集, Vol.10, No.5, pp.52-65, 2010.

25）湊文博, 秦吉弥, 常田賢一, 鍬田泰子, 山田雅行, 魚谷真基 : ウォーキング実験に基づく津波避難困難 地域の評価一和歌山県串本町を例として一，地域安 全学会梗概集, No.35, pp.17-20, 2014.

26) 湊文博, 秦吉弥, 中嶋唯貴, 小山真紀, 鍬田泰子, 山田雅行，常田賢一：避難余裕時間に基づく津波避 難困難区域の抽出手法に関する適用性の評価一1993 年北海道南西沖地震による奥尻島青苗地区を例とし て一，土木学会論文集 B3, Vol.72, No.2, pp.I_509-514, 2016.

(2017.2.2 受付)

\title{
PREDICTION OF STRONG MOTION AND DIFFICULT TIME FOR TSUNAMI EVACUATION IN TOBISHIMA, SAKATA CITY, JAPAN
}

\author{
Masaki YAMAUCHI, Yoshiya HATA, Yasuko KUWATA, \\ Maki KOYAMA and Tadayoshi NAKASHIMA
}

During a large scale scenario earthquake, huge tsunami with early travel time is striked in Tobishima, Sakata City, Japan. In this study, ground shaking characterisrtics in the tsunami attack area were evaluated using microtremor measurement with high density. The strong motions in Tobishima were then estimated based on the asperity models considering the ground shaking characteristics. Furthermore, the difficult time for tsunami evacuation during the earthquake was calculated using instantaneous instrumental seismic intensity. Finally, we discussed the influence of the strong motion on the tsunami evacuation based on the relationship between the travel time and the difficult time. 